\title{
The correlation of crystalline and elemental composition of urinary stones with a history of bacterial infections: TXRF, XRPD and PCR-DGGE studies
}

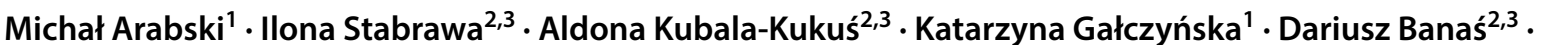 \\ Łukasz Piskorz ${ }^{4} \cdot$ Ewa Forma $^{5} \cdot$ Magdalena Bryśs $^{5} \cdot$ Waldemar Różański $^{6} \cdot$ Marek Lipiński ${ }^{6}$
}

Received: 28 February 2018 / Revised: 27 August 2018 / Accepted: 19 November 2018 / Published online: 27 November 2018

(c) The Author(s) 2018

\begin{abstract}
The aim of this study was to analyze the correlation between past bacterial infections and the type and chemical composition of urinary stones experienced by human patients. Bacteria have been recognized to contribute to urinary stones; however, the role of uropathogens in the development of specific stones has not been extensively investigated. The detection of past bacterial infection (eleven different bacterial species) in urinary stones from 83 patients was made on a DNA level using polymerase chain reaction (PCR) and denaturing gradient gel electrophoresis (DGGE) and correlated with the chemical composition of urinary stones measured using X-ray powder diffraction (XPRD) technique and their elemental composition by total reflection X-ray fluorescence (TXRF). In this study, two scenarios of urinary stones formation mediated by Proteus $\mathrm{sp}$. or Escherichia coli are presented. The first one is associated with Proteus spp. which dominated in $84 \%$ of infectious urinary stones and is strongly correlated with struvite and calcium phosphate, in whose matrix additionally strontium, phosphorus, potassium, nickel and zinc are detected. The formation of these stones is closely correlated with urease activity. The second scenario for urinary stone mineralization is associated with $E$. coli identified in weddellite stones, in which matrix iron was detected. In conclusion, the statistical correlations of bacterial infections with crystalline and elemental composition showed that in mixed bacterial infections, one scenario dominated and excluded the second one.
\end{abstract}

Keywords TXRF $\cdot$ XPRD $\cdot$ PCR-DGGE $\cdot$ Urinary stones $\cdot$ Escherichia coli $\cdot$ Proteus spp.

Electronic supplementary material The online version of this article (https://doi.org/10.1007/s00249-018-1338-7) contains supplementary material, which is available to authorized users.

Michał Arabski

arabski@ujk.edu.pl

1 Department of Biochemistry and Genetics, Institute of Biology, Jan Kochanowski University, Świętokrzyska St. 15, 25-406 Kielce, Poland

2 Institute of Physics, Jan Kochanowski University, Świętokrzyska St. 15, 25-406 Kielce, Poland

3 Holycross Cancer Center, Artwińskiego St. 3, 25-734 Kielce, Poland

4 St. John's God Hospital, Kosynierów Gdyńskich St. 61, 93-357 Łódź, Poland

5 Department of Cytobiochemistry, Faculty of Biology and Environmental Protection, University of Lodz, Pomorska St. 141/143, 90-236 Łódź, Poland

6 2nd Department of Urology, Medical University of Lodz, Pabianicka St. 62, 93-513 Łódź, Poland

\section{Introduction}

Urolithiasis and urinary tract infections are two urological diseases that may occur independently and simultaneously in the same patient. Urolithiasis occurs in about $10-12 \%$ of men and about $6 \%$ of women (Asplin et al. 2002; Desai et al. 2017). Urinary tract infections and stones may occur in patients with gout, urinary outflow obstruction and neurogenic bladder (Nseyo and Santiago-Lastra 2017). Additionally, a risk of urinary tract colonization by pathogens is higher in patients who have assumed all sorts of urinary catheters/stents (Klis et al. 2009; Chenoweth and Saint 2016). The possibility of the occurrence and interaction of infection and urolithiasis is common and that is why we tried to assess the frequency and type of pathogens which come into contact with the stone during its presence in the urinary tract.

The use of molecular techniques, based on polymerase chain reaction (PCR) and amplification of $16 \mathrm{~S}$ rDNA is a 
rapid and reliable way to identify microorganisms. The combination of PCR and denaturing gradient gel electrophoresis (DGGE) enables the identification of bacterial DNA in various types of urinary stones. DGGE is a sensitive tool for profiling complex microbial populations and direct comparisons can be made between samples run on the same gels. Moreover, DGGE over other profiling techniques gives the possibility of excising bands from the gel for amplification and sequencing (Davies et al. 2004; Tabit 2016). We have made attempts to identify the microorganisms colonizing the urinary tract in different periods of time during the development of urinary stones. On the basis of our previously published data (Kubala-Kukuś et al. 2017) in this study, we statistically analyzed correlations between the chemical composition of urinary stones measured using X-ray powder diffraction (XPRD) technique and their elemental composition determined by total reflection X-ray fluorescence (TXRF) with a history of bacterial infections. We decided to use PCR-DGGE techniques to detect bacterial species at the DNA level. In doing this we took into account the long time period for urinary stone formation and the importance of detecting only bacterial species in urine stone matrix, and not due to any current infection.

\section{Methods}

\section{Materials and samples' preparation procedures}

Urinary stones were obtained during therapeutic lithotomy with percutaneous nephrolithotomy (PCNL) or ureterorenoscopy (URS) from 83 patients (36 woman and 44 men) of Second Department of Urology, Medical University of Lodz, Poland. The XRPD measurements do not need an additional sample preparation procedure. In the case of TXRF analysis, each sample of human urinary stone was prepared according to the procedure presented elsewhere (Kubala-Kukuś et al. 2017). For genetic studies, DNA was extracted using a modified Swidsinki et al.'s method (Swidsinski et al. 1995). Stone samples of approximately $200 \mathrm{mg}$ were crushed in a $1.5 \mathrm{ml}$ Eppendorf tube and incubated with $600 \mu \mathrm{l}$ of $1 \%$ sodium dodecyl sulfate rotating overnight at room temperature. Lithium chloride solution $(7 \mathrm{~mol} / \mathrm{l})$ was added to a final concentration of $1.5 \mathrm{~mol} / \mathrm{l}$, for precipitating the interfering substances. The DNA was then extracted using QIAamp DNA Investigator Kit (QIAGENE, Hilden, Germany) according to the procedures provided by the manufacturer. For PCR-DGGE studies, the following bacteria were used as controls: Escherichia coli ATCC25922, Klebsiella pneumoniae ATCC13883, Morganella morganii ATCC25830, Proteus mirabilis ATCC10005, Proteus vulgaris ATCC6896, Providencia rettgeri ATCC9250, Providencia stuartii ATCC29914, Pseudomonas aeruginosa ATCC25668,
Serratia marcescens ATCC14764, Staphylococcus aureus ATCC25923 and Streptococcus pyogenes ATCC19615.

\section{Determination of the crystalline composition of urinary stones by XRPD technique}

X-ray powder diffraction measurements were performed in the Bragg-Brentano geometry using X'Pert Pro MPD diffractometer (PANalytical). This diffractometer is equipped with $\mathrm{Cu}$-anode $1.8 \mathrm{~kW}$ X-ray tube with linear exit window and PW3050/60 goniometer with an angular resolution of $0.001^{\circ}$. For X-rays diffracted on an analyzed sample, the position sensitive silicon strip detector ( $\mathrm{X}^{\prime}$ Celerator) with the crystal dimensions $15 \times 9 \mathrm{~mm}^{2}$ and 128 strips was used. The detector speeds up the data collection by measuring simultaneously about $2^{\circ}$ of $2 \theta$. The measurements were performed in the $2 \theta$ angular range from $5^{\circ}$ to $70^{\circ}$. Typical measurement time of one full angular scan was about $30 \mathrm{~min}$. Obtained diffractograms were analyzed qualitatively with Highscore 3.0e program using PDF-2 Release 2009 database of International Centre for Diffraction Data. The detailed information about XPRD methodology is presented elsewhere (Kubala-Kukuś et al. 2017).

\section{Determination of the elemental composition of urinary stones by TXRF technique}

Total reflection X-ray fluorescence measurements were performed with the S2 Picofox spectrometer (Bruker). The characteristic X-rays were excited in the samples with the $30 \mathrm{~W}$ Mo-anode X-ray tube operated at $50 \mathrm{kV}$ with an electron current of $0.6 \mathrm{~mA}$. The primary $\mathrm{X}$-ray beam from the tube, monochromated using the $\mathrm{Ni} / \mathrm{C}$ multilayer monochromator to $17.5 \mathrm{keV}$ energy, was directed onto the studied sample below the critical angle. Fluorescence X-rays from the samples were detected by Peltier-cooled XFlash silicon drift detector having an energy resolution about $160 \mathrm{eV}$ for the $\mathrm{Mn}-\mathrm{K} \alpha$ line. The measurements were performed in air. The Picofox spectrometer allows measurement of characteristic $\mathrm{X}$-ray of elements from $\mathrm{Mg}$ to $\mathrm{U}$ (with exception of $\mathrm{Zr}$ to Tc). With spectrometer software (SPECTRA 7), both qualitative analysis of the spectrum and the quantitative analysis of the sample content can be performed (Kubala-Kukuś et al. 2017). The validation of the TXRF technique was carried out by us before actual measurements by analyzing certified water solutions from Merck. The achieved accuracy is on the level of $5-10 \%$.

\section{Detection of the bacteria in urinary stones by PCR and DGGE}

The eubacterial primers ( $5^{\prime}$-ACTCCTACGGGAGGCAGC AG-3', 5'-GTATTACCGCGGCTGCTGGCAC-3') were used 
in amplification of all ribosomal eubacterial DNA. A 40-bp GC clamp was attached to the reverse primer to obtain PCR fragments suitable for DGGE analysis. A reaction mixture containing approximately $50 \mathrm{ng}$ of template DNA, PCR buffer (10 mM Tris-HCl, pH 8.3; $50 \mathrm{mM} \mathrm{KCl} ; 2.5 \mathrm{mM}$ $\mathrm{MgCl}_{2} ; 0.001 \%$ gelatin), a $0.2 \mathrm{mM}$ concentration of each PCR primer, a $0.2 \mathrm{mM}$ concentration of each deoxynucleoside triphosphate in a total volume of $50 \mu \mathrm{l}$ was prepared. The samples were first incubated for $5 \mathrm{~min}$ at $94{ }^{\circ} \mathrm{C}$ to denature the template DNA and subsequently cooled to $80^{\circ} \mathrm{C}$, at which point $2.5 \mathrm{U}$ of Taq DNA polymerase (Applied Biosystems Inc., Foster City, USA) was added. The amplification program was $94{ }^{\circ} \mathrm{C}$ for $2 \mathrm{~min} ; 35$ cycles of $94{ }^{\circ} \mathrm{C}$ for $30 \mathrm{~s}$, annealing for $1 \mathrm{~min}$ at $55^{\circ} \mathrm{C}$, and finally $68^{\circ} \mathrm{C}$ for $7 \mathrm{~min}$. PCR 16S rDNA fragments were loaded onto an $8 \%$ polyacrylamide gel, which was made with a denaturing gradient ranging from 30 to $50 \%$. The denaturant (100\%) contained $7 \mathrm{M}$ urea and $40 \%$ formamide. Gels were run at $130 \mathrm{~V}$ in $1 \times$ TAE ( $40 \mathrm{mM}$ Tris, $20 \mathrm{mM}$ acetic acid, $1 \mathrm{mM}$ EDTA, $\mathrm{pH}$ 8.0). After electrophoresis, gels were stained for $20 \mathrm{~min}$ in $5 \mu \mathrm{g} / \mathrm{ml}$ of ethidium bromide and de-stained for $10 \mathrm{~min}$ in $1 \times \mathrm{TAE}$.

\section{Band excision from DGGE gels, re-amplification}

DGGE gel bands were excised using a sterile scalpel, washed once in $1 \times \mathrm{PCR}$ buffer and incubated in the same buffer overnight at $4{ }^{\circ} \mathrm{C} ; 5 \mu \mathrm{l}$ of the buffer solution formed the template for PCR amplification. Re-amplification was conducted using the eubacterial PCR primers (with no 'GC clamps') depending on the primer set used in the DGGE, and with the same conditions as for the PCR preceding the DGGE analysis.

\section{Sequencing and sequence analysis}

To verify the specificity of the PCR product, the DNA band from the polyacrylamide gel was cut out, and the purified DNA was extracted with Gel extraction kit (QIAGEN, Hilden, Germany) and sequenced using the BigDye Terminator Cycle Sequencing Kit (Applied Biosystems Inc., Foster City, USA) on an ABI PRISM ${ }^{\mathrm{TM}} 377$ Genetic Analyzer (Applied Biosystems Inc., Foster City, USA). Analysis of the partial sequences was conducted using the Genbank DNA database and the BLAST algorithm. Identities of isolates were determined on the basis of the highest identity score.

\section{Statistical analysis}

The statistical analysis of the obtained data concentrated on the one side on the descriptive statistics of the elemental concentrations in urinary stone samples analyzed with the TXRF method, the goodness of fit tests for element concentration distributions, and on the multigroup comparison of element concentrations and elemental correlation analysis with application of the type of urine stone as a grouping factor. The statistical methods and procedures, as well as detailed results of performed analysis are presented in our previous work (Kubala-Kukuś et al. 2017). Summarizing, in elemental analysis, 21 elements were determined, i.e., 9 uncensored (P, K, $\mathrm{Ca}, \mathrm{Fe}, \mathrm{Zn}, \mathrm{Ni}, \mathrm{Br}, \mathrm{Sr}$ and $\mathrm{Pb}$ ) and 12 censored elements $(\mathrm{Mg}, \mathrm{S}, \mathrm{Cl}, \mathrm{Ti}, \mathrm{V}, \mathrm{Cr}, \mathrm{Mn}, \mathrm{Cu}, \mathrm{Se}$, $\mathrm{Rb}$, I and $\mathrm{Bi}$ ). The parameters of concentration distributions were calculated, in the case of censored element using survival approach and Kaplan-Meier estimator. XRPD measurements allowed specifying minerals present in the stones and, next, classifying the kidney stones.

On the other hand the main aim of the performed studies presented in this paper was to check the correlation of the crystalline and elemental composition of urinary stones with history of bacterial infections. In statistical analysis, the possible correlations were analyzed using Spearman's correlation coefficient which is a nonparametric measure of statistical dependence between two variables (both for numerical and ordinal variables). In these studies, the correlations between crystalline substances identified in urinary stones were calculated, then the correlations between species of bacteria, followed by the correlations between the chemical composition of urinary stones and species of bacteria, and finally the correlations between the concentration of the elements and the species of bacteria. For each value of Spearman's correlation coefficient, the statistical test was also performed verifying that it is statistically different from zero (statistically significant correlation). The correlation was interpreted as statistically significant for $p$ value less than $0.05(p<0.05)$. All calculations and statistical analyses were performed using STATISTICA version 11.0 (StatSoft, Poland).

\section{Results}

\section{DGGE analysis of bacterial DNA from urine stones using eubacterial-specific primers}

Using universal eubacterial primers targeting the 16S rRNA, we identified several bacterial species present in the urine stones. Overall, different bacterial species were detected: Escherichia coli (fragment 14), Klebsiella pneumoniae (fragment 7), Morganella morganii (fragment 8, 12), Proteus mirabilis (fragment 1), Proteus vulgaris (fragment 2, 13), Providencia rettgeri (fragment 4, 9), Providencia stuartii (fragment 11), Pseudomonas aeruginosa (fragment 14), Serratia marcescens (fragment 5, 10), Staphylococcus aureus (fragment 6), Streptococcus pyogenes (fragment 3) (Online Resource1). 
Table 1 BLAST analysis of urine stone-bacterial 16S rRNA sequences of excised fragments from DGGE gels

\begin{tabular}{ll}
\hline Species & Homology (\%) \\
\hline Escherichia coli ATCC 25922 & 92 \\
Klebsiella pneumoniae ATCC 13883 & 87 \\
Morganella morganii ATCC 25830 & 96 \\
Proteus mirabilis ATCC 10005 & 92 \\
Proteus vulgaris ATCC 6896 & 98 \\
Providencia rettgeri ATCC 9250 & 97 \\
Providencia stuartii ATCC 29914 & 91 \\
Pseudomonas aeruginosa ATCC 25668 & 94 \\
Serratia marcescens ATCC 14764 & 95 \\
Staphylococcus aureus ATCC 25923 & 97 \\
Streptococcus pyogenes ATCC 19615 & 94 \\
\hline
\end{tabular}

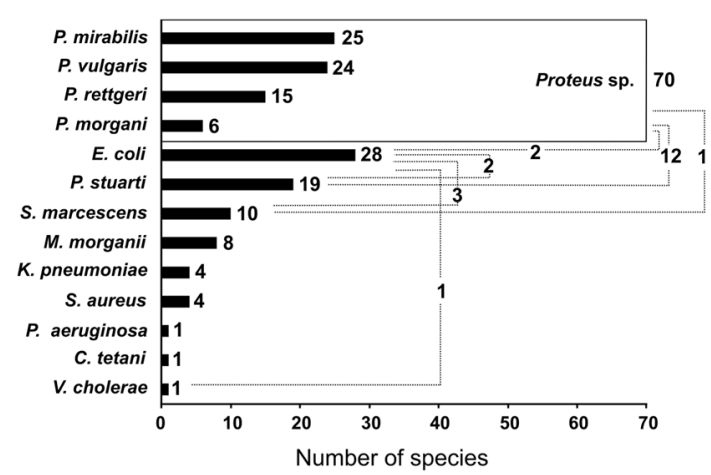

Fig. 1 The number of identified bacterial species in 83 urinary stones using DGGE-PCR method. The number of identified bacterial species in alone and mixed infections in different types of stones (dashed line) are denoted

The homology between the sequence obtained from the DGGE bands and the closest species from the database are presented in Table 1. Figure 1 shows that Proteus sp. dominated in tested urine stones $84 \%$, mainly $P$. mirabilis and P. vulgaris. In $17 \%$ of cases, $P$. stuartii was detected with Proteus spp. E. coli was the second most detected bacteria in urine stones (34\%). The other species were identified on the level in range from 5 to $12 \%$ : S. aureus, K. pneumoniae, M. morganii and S. marcescens, respectively. P. aeruginosa, $C$. tetani and $V$. cholerae were identified only in single cases.

\section{Crystalline and elemental composition of urinary stones: XRPD and TXRF techniques}

Figure 2 shows an example of the total reflection X-ray fluorescence (TXRF) spectrum and X-ray powder diffraction (XRPD) diffractogram of a human kidney stone sample. Figure 3 shows the crystalline composition of urinary stones. The stones contain several crystalline substances, namely,
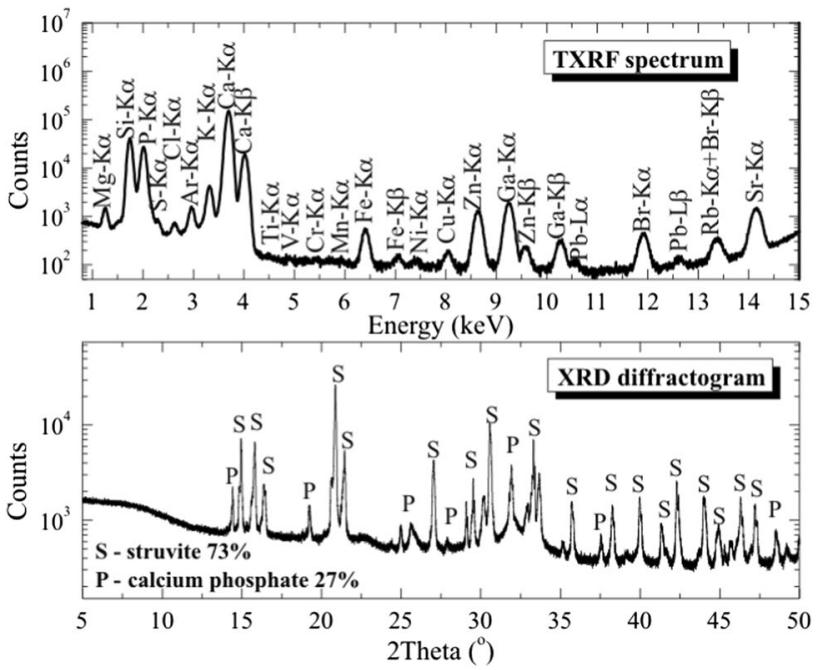

Fig. 2 The upper panel: an example of the total reflection X-ray fluorescence (TXRF) spectrum of a human kidney stone sample excited by the primary X-rays generated in a Mo-anode X-ray tube operated with voltage $U=50 \mathrm{kV}$ and current $I=600 \mu \mathrm{A}$. The measurement time was $30 \mathrm{~min}$. The lower panel: a X-ray powder diffraction (XRPD) diffractogram of a human kidney stone sample. The primary $\mathrm{X}$-rays were generated in a $\mathrm{Cu}$-anode $\mathrm{X}$-ray tube operated with voltage $U=45 \mathrm{kV}$ and current $I=40 \mathrm{~mA}$

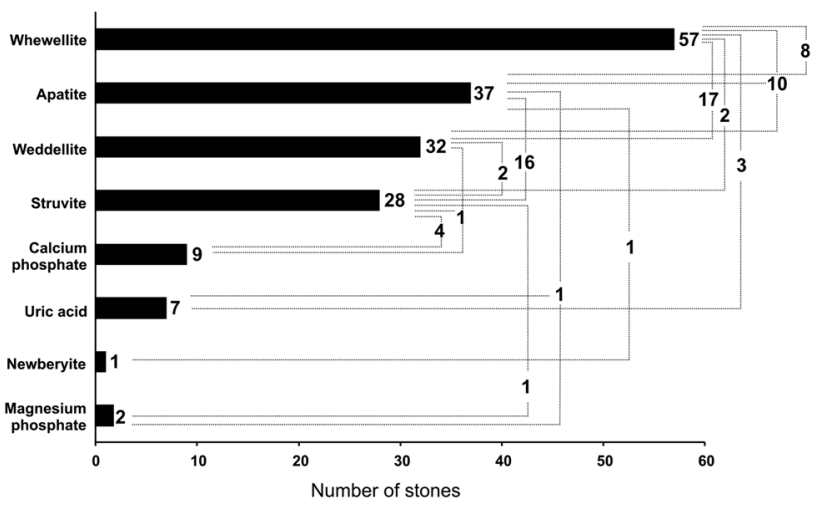

Fig. 3 The number of urinary stones in which crystalline composition was determined using XRPD method. The number of urinary stones in which single or complex crystalline structures were detected (dashed line) are denoted

apatite $\left(\mathrm{Ca}_{5}\left[(\mathrm{~F}, \mathrm{Cl}, \mathrm{OH})\left(\mathrm{PO}_{4}\right)_{3}\right]\right)$, struvite $\left(\mathrm{NH}_{4} \mathrm{MgPO}_{4} \cdot 6 \mathrm{H}_{2} \mathrm{O}\right.$, uric acid $\left(\mathrm{C}_{5} \mathrm{H}_{4} \mathrm{~N}_{4} \mathrm{O}_{3}\right)$, weddellite $\left(\mathrm{Ca}(\mathrm{COO})_{2} \cdot 2 \mathrm{H}_{2} \mathrm{O}\right)$, whewellite $\left(\mathrm{Ca}(\mathrm{COO}) 4_{2} \cdot \mathrm{H}_{2} \mathrm{O}\right)$, magnesium phosphate $\left(\mathrm{Mg}_{3}\left(\mathrm{PO}_{4}\right)_{2}\right)$ and calcium phosphate $\left(\mathrm{Ca}_{3}\left(\mathrm{PO}_{4}\right)_{2}\right)$. Eightythree urinary stones examined by XPRD were divided into groups depending on their chemical composition: whewellite (24.1\% alone; $20.5 \%$ with weddellite; $12 \%$ with weddellite and apatite; $9.6 \%$ with apatite; $2.4 \%$ with struvite), apatite (2.4\% alone; $19.3 \%$ with struvite; $1.2 \%$ with uric acid stones and magnesium phosphate), weddellite ( $2.4 \%$ alone or with 
struvite; $1.2 \%$ with calcium phosphate and struvite), struvite ( $2.4 \%$ alone; $4.8 \%$ with calcium phosphate), calcium phosphate ( $4.8 \%$ alone), and uric acid (3.6\% alone). Generally, the stones of mixed composition which contained minerals from different chemical groups dominated (79.5\%), mainly whewellite with weddellite or apatite with struvite. The most frequently determinated is whewellite $>$ apatite $>$ weddellite $>$ struvite in urinary stones. Detailed results of XRPD as well as TXRF analyses on elemental composition of 83 urinary stones used in this study are previously published (Kubala-Kukuś et al. 2017).

\section{Incidence analysis of the bacterial species versus the chemical and elemental composition of urinary stones}

Table 2 shows the correlation between crystalline substances identified in urinary stones. It seems to be significant that two positive correlations of chemical compositions dominate in analyzed probes: weddellite with whewellite $(0.268)$ or struvite with calcium phosphate (0.243). It is important that both chemical compositions are mutually exclusive: struvite with whewellite or weddellite $(-0.727$ and -0.303 , respectively) and calcium phosphate with whewellite $(-0.349)$. The analyses of Spearman's rank coefficients between species of bacteria identified in urinary stones (Table 3 ) show that Proteus species are correlated together (0.253-0.473) in contrast to E. coli $(-0.286$ to -0.335$)$. Similarly, statistical analyses in this study shown that the presence of E. coli in urinary stones is mutually exclusive to the presence of M. morganii (-0.233). M. morganii as previously classified Proteus morganii, belongs to the tribe of the family Enterobacteriaceae and it role in urinary stone formation is similar to Proteus spp. in contrast to E. coli. Table 4 shows that bacterial species are strongly positively correlated with chemical composition of urinary stones: Proteus spp. mainly with struvite $(0.261-0.420)$ and newberyite
(P. rettgeri; 0.235$)$ but not correlated with weddellite and whewellite $(-0.221$ to -0.349$)$. The presence of $E$. coli is characteristic for weddellite (0.272) and whewellite (0.207) but not for struvite $(-0.240)$. Moreover, $M$. morganii was identified in whewellite urinary stones $(0.221)$ but does not contain struvite $(-0.233)$ or apatite $(-0.211)$. The analysis of elemental composition of urinary stones (Table 5) shows that the presence of Proteus spp. is correlated mainly with strontium (3 species; 0.256-295), phosphorus (3 species; 0.273-0.333), potassium (2 species; 0.328, 0.398), nickel (only P. morgani; 0.258 ) and zinc (only P. mirabilis; 0.284 ). E. coli in urinary stones is correlated only with iron $(0.243)$ but not with potassium $(-0.225)$.

\section{Discussion}

In this study, we identified DNA of bacterial uropathogens in 83 urinary stones using PCR and DGGE methods and correlated with their crystalline and elemental composition. Crystalline material is the primary constituent of most human urinary tract stones. Additionally, the urinary stones contain macromolecules, and other cellular and elemental components, termed the matrix, and reflect the urine chemistry and abnormalities in urinary tract physiology. These physico-chemical conditions have effects on the process of stone development and might be caused by bacterial infections. Although stones with mixed composition in different configurations dominate (79.5\%), their statistical correlations with a history of infections show two general scenarios of particular "chemico-bacterial" compositions.

The first one is associated with Proteus spp. which dominated in $84 \%$ of infectious urinary stones measured in this study and is strongly correlated with struvite and calcium phosphate, in whose matrix additionally strontium, phosphorus, potassium, nickel and zinc are detected. Urinary tract infection by Proteus spp. occurs in patients requiring

Table 2 Correlation between crystalline substances identified in urinary stones given by values of nonparametric Spearman's rank correlation coefficients

\begin{tabular}{|c|c|c|c|c|c|c|c|c|}
\hline & Uric acid & Apatite & Newberyite & Struvite & Weddellite & Whewellite & Calcium phosphate & $\begin{array}{l}\text { Mag- } \\
\text { nesium } \\
\text { phosphate }\end{array}$ \\
\hline Uric acid & - & -0.185 & -0.034 & -0.217 & -0.240 & -0.075 & 0.034 & -0.034 \\
\hline Apatite & -0.185 & - & 0.123 & 0.180 & -0.063 & -0.126 & -0.079 & -0.099 \\
\hline Newberyite & -0.034 & 0.123 & - & -0.079 & -0.087 & -0.164 & -0.039 & -0.012 \\
\hline Struvite & -0.217 & 0.180 & -0.079 & - & -0.303 & -0.727 & 0.243 & 0.155 \\
\hline Weddellite & -0.240 & -0.063 & -0.087 & -0.303 & - & 0.268 & -0.037 & -0.087 \\
\hline Whewellite & -0.075 & -0.126 & -0.164 & -0.727 & 0.268 & - & -0.349 & -0.164 \\
\hline Calcium phosphate & 0.034 & -0.079 & -0.039 & 0.243 & -0.037 & -0.349 & - & -0.039 \\
\hline Magnesium phosphate & -0.034 & -0.099 & -0.012 & 0.155 & -0.087 & -0.164 & -0.039 & - \\
\hline
\end{tabular}

Statistically significant correlations are marked in bold $(p$ value $<0.05)$ 


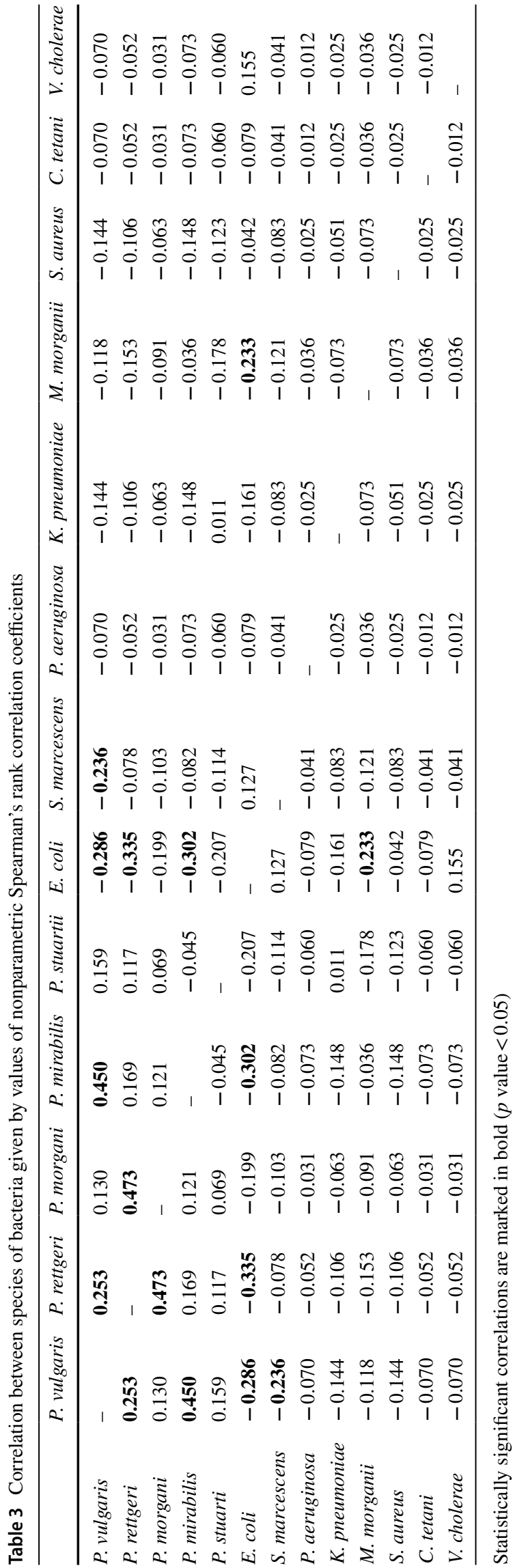

long-term maintenance of catheters in the urinary tract, and this type of infection coexists with nephrolithiasis and bladder lithiasis (Burall et al. 2004). The chemical composition of stones in the presence of Proteus spp. is well-known and this study confirms that the mechanism of struvite mineralization is associated with urease activity. The presence of urease-positive Proteus spp. in urine causes the elevation of the concentration of ammonia and carbon dioxide. Ammonia creates ammonium ion and an increase in $\mathrm{pH}$ of urine takes place. Carbon dioxide reacts with water creating the carbonic acid. Additionally, the formation of phosphate ions in urine is observed. These above chemical reactions lead to the supersaturation and crystallization of magnesium and calcium salts as struvite $\left(\mathrm{MgNH}_{4} \mathrm{PO}_{4} \cdot 6 \mathrm{H}_{2} \mathrm{O}\right)$ and carbonate apatite $\left(\mathrm{Ca}_{10}\left(\mathrm{PO}_{4}\right)_{6} \cdot \mathrm{CO}_{3}\right)$, respectively (Rodman 1999; Torzewska and Rozalski 2014). Urease has a nickel-containing active site (Mobley and Island 1995). Moreover, zinc uptake by $P$. mirabilis provides a competitive advantage to other pathogenic bacteria, including uropathogenic $E$. coli (Sabri et al. 2009). This metal is required for virulence factors regulations, such as flagella and ZapA metalloprotease. Bacteria use flagella to swim through liquids and toward chemical gradients. This motility (swarming) plays a crucial role in $P$. mirabilis virulence and stimulates the expression of the other virulence factors, including urease and ZapA protease. Regulation of flagella is mediated through the class 1 flagellar master regulator genes $f h D C$, as $\mathrm{FlhD}_{4} \mathrm{C}_{2}$ protein, possessing zinc binding site. It indicates that zinc plays an important role in flagella expression. Moreover, the presence of functional zinc uptake system (znuACB) by $P$. mirabilis confirms importance of zinc for bacteria metabolism (Belas et al. 2004; Schaffer and Melanie 2015). Strontium has similar physico-chemical properties as calcium, and its absorption and excretion follow that of calcium (Vezzoli et al. 1998).

The second scenario for urinary stone mineralization presented in this study is associated with $E$. coli identified in mainly weddellite stones, in which iron was detected. Generally, published studies indicate that $E$. coli is a cause of urinary tract infections in about $80 \%$ of patients (Ronald 2003; Ramchandani et al. 2017). It seems to be more likely, that E. coli-mediated scenario is more often observed due to the frequency of this bacterial infection. However, mainly Proteus spp. may serve as centers for heterogeneous nucleation and urinary stones growth and our work confirms clinical studies which indicate urease activity as crucial in such urinary stone formation. The results of genetic and biophysical studies presented in this work showed that the first scenario of Proteus stimulated urinary stone formation that is dominating from the clinical point of view.

Barr-Beare et al. showed that E. coli was identified in patients by calcium oxalate stone culture. E. coli selectively aggregated on and around calcium oxalate monohydrate 
Table 4 Correlation between chemical composition of urinary stones and species of bacteria given by values of nonparametric Spearman's rank correlation coefficients calculated for species of bacteria

\begin{tabular}{|c|c|c|c|c|c|c|c|c|}
\hline \multirow[t]{2}{*}{ Species of bacteria } & \multicolumn{8}{|c|}{ Type of stone } \\
\hline & Uric acid & Apatite & Newberyite & Struvite & Weddellite & Whewellite & Calcium phosphate & $\begin{array}{l}\text { Magnesium } \\
\text { phosphate }\end{array}$ \\
\hline P. vulgaris & -0.194 & 0.123 & -0.070 & 0.332 & -0.068 & -0.314 & 0.034 & -0.070 \\
\hline P. rettgeri & -0.143 & 0.146 & 0.235 & 0.261 & -0.115 & -0.290 & 0.038 & -0.052 \\
\hline P. morgani & -0.085 & 0.030 & -0.031 & 0.194 & -0.221 & -0.112 & 0.052 & -0.031 \\
\hline P. mirabilis & -0.199 & 0.151 & -0.073 & 0.420 & -0.034 & -0.349 & 0.193 & 0.168 \\
\hline P. stuarti & 0.247 & 0.031 & -0.060 & 0.036 & -0.137 & -0.188 & -0.006 & -0.060 \\
\hline E. coli & -0.033 & 0.027 & -0.079 & -0.240 & 0.272 & 0.207 & -0.003 & -0.079 \\
\hline S. marcescens & 0.154 & -0.034 & -0.041 & -0.186 & 0.087 & 0.170 & -0.129 & -0.041 \\
\hline P. aeruginosa & 0.364 & -0.099 & -0.012 & -0.079 & -0.087 & 0.075 & -0.039 & -0.012 \\
\hline K. pneumoniae & 0.134 & 0.025 & -0.025 & -0.042 & 0.053 & 0.031 & -0.078 & -0.025 \\
\hline M. morganii & 0.048 & -0.211 & -0.036 & -0.233 & 0.077 & 0.221 & 0.017 & -0.036 \\
\hline S. aureus & -0.068 & 0.138 & -0.025 & -0.161 & -0.063 & 0.152 & -0.078 & -0.025 \\
\hline C. tetani & -0.034 & 0.123 & -0.012 & 0.155 & -0.087 & 0.075 & -0.039 & -0.012 \\
\hline V. cholerae & -0.034 & -0.099 & -0.012 & -0.079 & -0.087 & 0.075 & -0.039 & -0.012 \\
\hline
\end{tabular}

Statistically significant correlations are marked in bold $(p$ value $<0.05)$

Table 5 Correlation between element concentrations and species of bacteria given by values of nonparametric Spearman's rank correlation coefficients

\begin{tabular}{|c|c|c|c|c|c|c|c|c|c|}
\hline \multirow[t]{2}{*}{ Species of bacteria } & \multicolumn{9}{|l|}{ Element } \\
\hline & $\mathrm{P}$ & $\mathrm{K}$ & $\mathrm{Ca}$ & $\mathrm{Fe}$ & $\mathrm{Ni}$ & $\mathrm{Zn}$ & $\mathrm{Br}$ & $\mathrm{Sr}$ & $\mathrm{Pb}$ \\
\hline P. vulgaris & 0.311 & 0.328 & -0.112 & -0.162 & -0.114 & 0.187 & 0.048 & 0.180 & 0.091 \\
\hline P. rettgeri & 0.273 & 0.165 & 0.034 & -0.302 & 0.029 & 0.146 & 0.001 & 0.256 & 0.067 \\
\hline P. morgani & 0.206 & 0.198 & 0.101 & -0.153 & 0.258 & 0.165 & -0.033 & 0.295 & 0.019 \\
\hline P. mirabilis & 0.333 & 0.398 & -0.102 & 0.116 & -0.094 & 0.284 & -0.082 & 0.270 & 0.047 \\
\hline P. stuarti & -0.072 & 0.038 & -0.213 & -0.029 & -0.084 & -0.134 & -0.026 & -0.126 & -0.134 \\
\hline E. coli & -0.187 & -0.225 & 0.103 & 0.243 & 0.056 & -0.096 & 0.088 & -0.114 & 0.149 \\
\hline S. marcescens & -0.188 & -0.107 & -0.051 & 0.002 & 0.057 & -0.154 & 0.008 & -0.168 & -0.110 \\
\hline P. aeruginosa & -0.166 & -0.023 & -0.175 & -0.161 & -0.184 & -0.157 & 0.092 & -0.175 & -0.175 \\
\hline K. pneumoniae & -0.049 & -0.066 & 0.021 & -0.073 & 0.077 & 0.073 & -0.204 & -0.023 & -0.059 \\
\hline M. morganii & -0.196 & -0.070 & 0.147 & 0.140 & 0.061 & -0.184 & 0.063 & -0.089 & 0.000 \\
\hline S. aureus & -0.054 & -0.197 & 0.002 & -0.195 & 0.131 & 0.085 & 0.042 & 0.028 & 0.127 \\
\hline C. tetani & 0.069 & 0.005 & 0.120 & -0.088 & 0.161 & 0.171 & 0.051 & 0.083 & -0.018 \\
\hline V. cholerae & -0.111 & -0.115 & -0.074 & 0.101 & -0.065 & -0.138 & -0.041 & -0.101 & 0.115 \\
\hline
\end{tabular}

Statistically significant correlations are marked in bold $(p$ value $<0.05)$ crystals (whewellite) in in vitro studies (Barr-Beare et al. 2015). Our study shows that $E$. coli is statistically significantly correlated with whewellite and weddellite stones. Low availability of iron is a major limiter of bacterial growth during host colonization, so many pathogenic bacteria, such as UPEC, evolved specific iron-transport systems and number of chelating compounds (siderophores). Iron is a cofactor of many bacterial proteins, which are involved in electron transport, reactive oxygen species detoxification, amino acid or nucleoside synthesis.

Interestingly, the aforementioned scenarios of urinary stones formation mediated by Proteus spp. and E. coli are totally independent. The statistical correlations of bacterial infections with crystalline and elemental composition of bladder stones showed that in mixed bacterial infections, one scenario dominated and excluded the second one. In our opinion, this is the most important and new observation presented in this study.

Additionally, we observed in this study that $P$. stuartii was identified in various types of analyzed stones, which is surprising because this pathogen corresponds to only $3 \%$ of urinary tract infections described in literature. The biophysical analyses in this study confirm that $P$. stuartii as an uropathogen with similar biochemical activity mainly to 
Proteus spp., might play an important role in urinary stone formation (O'Hara et al. 2000). P. aeruginosa is a cause of urinary tract infection in 4.5-7.6\% (Akkoyun et al. 2008; Piljić et al. 2009). In our study, Pseudomonas aeruginosa was identified only in the uric and mixed stones. K. pneumoniae may be the cause of urinary tract infections from 8.5 to $10 \%$ (Johansen et al. 2006). We found it in all kinds of stones, from $2.7 \%$ in infected phosphate stones to $14.3 \%$ in the stones of uric acid. M. morganii was found in the urate, oxalic and mixed stones, but it has not been identified in phosphate ones. M. morganii may cause bacteriuria in $37 \%$ of patients with urinary tract infections (Lee and Liu 2006).

Acknowledgements The equipment was purchased thanks to the financial support of the European Regional Development Fund in the framework of the Development of the Eastern Poland Program (contract no. POPW.01.01.00-26-013/09-04).

Open Access This article is distributed under the terms of the Creative Commons Attribution 4.0 International License (http://creativeco mmons.org/licenses/by/4.0/), which permits unrestricted use, distribution, and reproduction in any medium, provided you give appropriate credit to the original author(s) and the source, provide a link to the Creative Commons license, and indicate if changes were made.

\section{References}

Akkoyun S, Kuloglu F, Tokuc B (2008) Etiologic agents and risk factors in nosocomial urinary tract infections. Mikrobiyol Bul 42:245-254

Asplin JR, Parks JH, Nakagawa Y, Coe FL (2002) Reduced crystallization inhibition by urine from women with nephrolithiasis. Kidney Int 61:1821-1829. https://doi.org/10.104 6/j.1523-1755.2002.00307.x

Barr-Beare E, Saxena V, Hilt EE et al (2015) The interaction between enterobacteriaceae and calcium oxalate deposits. PLoS One 10:117. https://doi.org/10.1371/journal.pone.0139575

Belas R, Manos J, Suvanasuthi R (2004) Proteus mirabilis ZapA metalloprotease degrades a broad spectrum of substrates, including antimicrobial peptides. Infect Immun 72:5159-5167. https://doi. org/10.1128/IAI.72.9.5159

Burall LS, Harro JM, Li X et al (2004) Proteus mirabilis genes that contribute to pathogenesis of urinary tract infection: identification of 25 signature-tagged mutants attenuated at least 100fold. Infect Immun 72:2922-2938. https://doi.org/10.1128/ IAI.72.5.2922-2938.2004

Chenoweth CE, Saint S (2016) Urinary tract infections. Infect Dis Clin N Am 30:869-885. https://doi.org/10.1016/j.idc.2016.07.007

Davies CE, Hill KE, Wilson MJ, Stephens P, Hill CM, Harding KG, Thomas DW (2004) Use of 16 S ribosomal DNA PCR and denaturing gradient gel electrophoresis for analysis of the microfloras of healing and nonhealing chronic venous leg ulcers. J Clin Microbiol 42:3549-3557. https://doi.org/10.1128/ JCM.42.8.3549-3557.2004

Desai M, Sun Y, Buchholz N et al (2017) Treatment selection for urolithiasis: percutaneous nephrolithotomy, ureteroscopy, shock wave lithotripsy, and active monitoring. World J Urol 35:1395-1399. https://doi.org/10.1007/s00345-017-2030-8

Johansen BTE, Cek M, Naber KG et al (2006) Hospital acquired urinary tract infections in urology departments: pathogens, susceptibility and use of antibiotics. Data from the PEP and PEAP-studies. Int Antimicrob Agents 28:91-107. https://doi.org/10.1016/j.ijant imicag.2006.05.005

Klis R, Korczak-Kozakiewicz E, Denys A et al (2009) relationship between urinary tract infection and self-retaining Double-J catheter colonization. J Endourol 23:1015-1019. https://doi. org/10.1089/end.2008.0518

Kubala-Kukuś A, Arabski M, Stabrawa I et al (2017) Application of TXRF and XRPD techniques for analysis of elemental and chemical composition of human kidney stones. X-Ray Spectrom 46:412-420. https://doi.org/10.1002/xrs.2778

Lee I-K, Liu J-W (2006) Clinical characteristics and risk factors for mortality in Morganella morganii bacteremia. J Microbiol Immunol Infect 39:328-334

Mobley HLT, Island MD (1995) Molecular biology of microbial ureases. Microbiol Rev 59:451-480

Nseyo U, Santiago-Lastra Y (2017) Long-term complications of the neurogenic bladder. Urol Clin North Am 44:355-366. https://doi. org/10.1016/j.ucl.2017.04.003

O'Hara CM, Brenner FW, Miller JM (2000) Classification, identification, and clinical significance of Proteus, Providencia, and Morganella. Clin Microbiol Rev 13:534-546

Piljić D, Ahmetagić S, Piljić D et al (2009) Etiological factors of community acquired urinary tract infections in hospitalized patients. Med Arh 63:128-132

Ramchandani M, Manges AR, Debroy C et al (2017) Possible animal origin of human-associated, multidrug-resistant, uropathogenic Escherichia coli. Clin Infect Dis 40:251-257. https://doi. org/10.1086/426819

Rodman J (1999) Struvite stones. Nephron 81:50-59

Ronald A (2003) The etiology of urinary tract infection: traditional and emerging pathogens. Dis Mon 49:71-82. https://doi.org/10.1016/ S0011-5029(03)90001-0

Sabri M, Houle S, Dozois CM (2009) Roles of the extraintestinal pathogenic Escherichia coli ZnuACB and ZupT zinc transporters during urinary tract infection. Infect Immun 77:1155-1164. https://doi.org/10.1128/IAI.01082-08

Schaffer JN, Melanie MP (2015) Proteus mirabilis and urinary tract infections. Microbiol Spectr 3:1-66. https://doi.org/10.1128/micro biolspec.UTI-0017-2013.Proteus

Swidsinski A, Ludwig W, Pahlig H, Priem F (1995) Molecular genetic evidence of bacterial colonization of cholesterol gallstones. Gastroenterology 108:860-864. https://doi.org/10.1016/00165085(95)90461-1

Tabit FT (2016) Advantages and limitations of potential methods for the analysis of bacteria in milk: a review. J Food Sci Technol 53:42-49. https://doi.org/10.1007/s13197-015-1993-y

Torzewska A, Rozalski A (2014) Inhibition of crystallization caused by Proteus mirabilis during the development of infectious urolithiasis by various phenolic substances. substances. Microbiol Res 169:579-584. https://doi.org/10.1016/j.micres.2013.09.020

Vezzoli G, Baragetti I, Zerbi S et al (1998) Strontium absorption and excretion in subjects: relation to calcium metabolism. Clin Chem 44:586-590 